\title{
Pengaruh Kecerdasan Emosional Terhadap Komitmen Organisasi Melalui Kepuasan Kerja Sebagai Variabel Mediasi pada Bank DKI Kantor Cabang Surabaya
}

\author{
Riza Mutimma Auda \\ Universitas Negeri Surabaya \\ rizamutimma@gmail.com
}

\begin{abstract}
DKI Bank is a commercial bank and Regional Enterprises which is owned by Jakarta Provincial Government and PD Pasar Jaya. DKI Bank now has grown into a commercial bank that has IDR 30.74 trillion assets, with the office network reached 221 offices in Jakarta and other major cities in Indonesia, and 2,549 human resources employee and range of banking products and services to more than one million customers.

This rapid development occurs because of their employees who properly implement the organization's commitment to the company for the betterment of the company. Organizational commitment cannot be separated from emotional intelligence employee and satisfaction work which is obtained by employees. This study aims to identify and explain the influence of emotional intelligence toward organizational commitment through job satisfaction as a mediating variable. This is causal research using quantitative approach. The sampling technique using 72 respondents saturated sample and collected as many as 64 respondents in DKI Bank Branch Office Surabaya. The statistical analysis used is Structural Equation Modeling (SEM) with the support of smartPLS software.

This study results explains that emotional intelligence has positive and significant effect on job satisfaction. Job satisfaction has positive effect and significant on organizational commitment. Emotional intelligence has positive and significant effect on organizational commitment. Job satisfaction mediates the influence of emotional intelligence on organizational commitment.
\end{abstract}

Keywords : Emotional Intelligence, Job Satisfaction, Organizational Commitment

\section{PENDAHULUAN}

Dalam mempersiapkan sumber daya manusia menghadapi Asian Free Trade Area (AFTA) dan Masyarakat Ekonomi Asean (MEA) dalam era persaingan global dibutuhkan keterampilan dan kecerdasan khusus untuk bertahan. Kebutuhan dan kemajuan teknologi yang terus berkembang mengharuskan sumber daya manusia mengikuti arus tersebut. Keadaan menyesuaikan diri dengan lingkungan sekitar merupakan keadaan dimana seseorang harus cerdas membawa dirinya supaya bermanfaat untuk segala sesuatu di sekitarnya. Kecerdasan emosional sendiri yang dapat menggambarkan hal tersebut. "Kecerdasan emosional adalah kemampuan untuk memahami secara efektif, tangkas, mengerti, mengelola emosi untuk diri sendiri dan emosi orang lain secara positif dan produktif “ (Kishan dan Sebastian, 2014). 


\section{Riza Mutimma Auda - Pengaruh Kecerdasan Emosional Terhadap Komitmen ...}

Artinya kecerdasan emosional adalah kemampuan untuk memotivasi diri dalam mengendalikan emosi pada diri sendiri dan orang lain untuk mencapai keberhasilan dalam aspek kehidupan. Dapat ditarik pendapat bahwa kecerdasan emosional dibutuhkan dalam diri setiap orang.

Peneliti lain yang ikut mempopulerkan kecerdasan emosional adalah Cooper dalam Seyal dan Afzaal (2012), penelitian tentang emosi di tempat kerja menunjukkan bahwa emosi dapat mendorong peningkatan produktivitas, inovasi, dan prestasi individu, tim dan organisasi. Penelitian tersebut mengambarkan adanya keselarasan antara kecerdasan emosional terhadap individu tersebut dan organisasi yang dianutnya. Untuk bertahan diantara organisasinya seseorang harus memiliki kecerdasan emosional terutama dalam lingkungan kerja.

Menurut Goreishi et al. (2014) konsep kecerdasan emosional telah digunakan oleh otoritas administratif di banyak tempat kerja untuk menjelaskan masalah yang berkaitan dengan kepuasan kerja, kinerja, absensi, komitmen organisasi dan kepemimpinan. Dalam psikologi sosial dan organisasi, kecerdasan emosional disebutkan sebagai prediktor penting dari organisasi termasuk kepuasan kerja. Hal tersebut didukung oleh Ezzatabadi et al. (2013) juga membahas mengenai gagasan kecerdasan emosional dapat diterapkan dalam banyak permasalahan di tempat kerja termasuk terhadap kepuasan kerja dan komitmen organisasi.
Menurut Sopiah (2008: 170) kepuasan kerja merupakan suatu tanggapan emosional seseorang terhadap situasi dan kondisi kerja. Tanggapan emosional bisa berupa perasaan puas atau tidak puas. Menurut Sinambela (2012:255) "seseorang yang merasa puas dalam pekerjaannya akan memiliki motivasi, komitmen pada organisasi dan partisipasi kerja yang tinggi, dan terus memperbaiki kinerjanya. Kepuasan kerja akan berhubungan dengan keterikatan pegawai pada organisasinya." Menurut Lee Kelly et al. dalam Mohammed dan Eleswed (2013) seorang karyawan yang puas cenderung lebih kreatif, fleksibel, inovatif dan setia. Selanjutnya, kepuasan kerja dapat digunakan sebagai penilaian yang luas. Kepuasan kerja sendiri menggambarkan sikap yang diberikan seorang individu atas pekerjaanya sehingga tercipta rasa nyaman ketika individu tersebut berada dalam organisasinya.

Perusahaan berlomba-lomba memenuhi segala kebutuhan karyawan dengan tujuan mempertahankan komitmen organisasi setiap karyawannya. Komitmen organisasi menjadi hal penting yang ada pada diri seorang karyawan ketika berada di sebuah perusahaan. Pendapat Porter et al. dalam Madi et al. (2012) komitmen organisasi terbentuk secara internal atau seperangkat niat dalam meningkatkan keinginan karyawan untuk tetap berada dalam organisasi dengan menerima tujuan dan nilai perusahaannya. Artinya komitmen organisasi adalah keinginan seseorang untuk tetap berada pada organisasinya. Keinginan tersebut 
didasari dengan adanya usaha untuk menerima norma dan nilai yang berlaku di organisasinya. Dibutuhkannya komitmen organisasi terhadap setiap karyawan untuk perusahaannya dengan tujuan karyawan tetap setia terhadap keadaan perusahaan dalam keadaan apapun.

Menurut Aisyah (2012) dalam penelitiannya menyatakan adanya pengaruh langsung antara kecerdasan emosional dengan komitmen organisasi. Hal tersebut didukung oleh beberapa peneliti lain diantaranya: Atmaja et al. (2015), Raza et al. (2014), Kishan dan Sebastian (2014), Mohamadkhani dan Lalardi (2012), bahwa kecerdasan emosional memiliki pengaruh terhadap komitmen organisasi.

Namun berdasarkan hasil penelitian Aghdasi et al. (2011) membuktikan bahwa kecerdasan emosional tidak berdampak pada komitmen organisasi. Adanya perbedaan penelitian sebelumnya antara kecerdasan emosional dan komitmen organisasi menjadikan peneliti tertarik untuk meneliti pengaruh kecerdasan emosional terhadap komitmen organisasi.

Najafi et al. mengungkapkan dalam penelitiannya, kepuasan kerja berpengaruh positif terhadap komitmen organisasi. Hal tersebut didukung oleh peneliti lain yaitu: Karim dan Rehman (2012), Tiur A. (2013), Mangkunegara et al. (2015), Farzeen et al. (2015), bahwa kepuasan kerja memiliki pengaruh terhadap komitmen organisasi

Namun hasil penelitian Novebry dan Eddy (2013) dalam peneltiannya
"Pengaruh Kualitas Leader Member Exchange Terhadap Produktivitas Kerja Melalui Kepuasan Kerja dan Komitmen Organisasional Pada PT. Nutrifood Surabaya" membuktikan kepuasan kerja tidak berpengaruh signifikan terhadap komitmen organisasi. Perbedaan yang terjadi pada penelitian sebelumnya antara pengaruh kepuasan kerja dan komitmen organisasi menjadi penyebab hal tersebut untuk perlu dilakukan penelitian kembali.

Dalam penelitian yang dilakukan Fatima et al. (2010) kecerdasan emosional memiliki dampak yang signifikan dan positif terhadap kepuasan kerja. Peneliti lain yang sependapat bahwa kecerdasan emosional memiliki pengaruh terhadap kepuasan kerja diantaranya: Sandhu (2015), Orhan dan Dincer (2012)

Tetapi hasil penelitian yang berbeda dibuktikan oleh Aghdasi et al. (2011) dalam penelitiannya mengindikasi kecerdasan emosional tidak berpengaruh langsung terhadap kepuasan kerja, dan komitmen organisasi. Timbulnya perbedaan hasil penelitian yang telah dilakukan sebelumnya antara pengaruh kecerdasan emosional dan komitmen organisasi menjadikan adanya pengaruh kedua variabel tersebut untuk perlu dilakukan penelitian kembali.

Bank DKI adalah Bank Umum dan Badan Usaha Milik Daerah yang memiliki aset 30,74 triliun dengan jaringan kantor mencapai 221 kantor yang tersebar di seluruh Indonesia. Dalam hal sumber daya manusia Bank DKI memiliki 2.549 karyawan serta 


\section{Riza Mutimma Auda - Pengaruh Kecerdasan Emosional Terhadap Komitmen ...}

ragam produk dan layanan perbankan kepada lebih dari 1 juta nasabah.

Bank DKI kantor cabang Surabaya terus melakukan transformasi menjadi The Great Company dan Center of Excellence, memiliki Human Resources Excellence, Service Excellence, Performance Excellent, penerapan $G C G$ Excellence serta CSR Excellence sesuai dengan pedoman Bank DKI yang menjadi modal dasar yang kuat untuk pertumbuhan dan peningkatan kinerja perusahaan serta sebagai kerangka dasar Bank DKI yang berkesinambungan di masa mendatang. Salah satunya pada tahun 2015 Bank DKI memperoleh penghargaan juara ke 3 service excellence Bank Pemerintah Daerah oleh Bank Indonesia.

Human Resources Excellence adalah upaya menghasilkan sumberdaya manusia yang berkualitas baik untuk perusahaan diantaranya dengan adanya pelatihan kreatifitas karyawan, jenjang karir, pengawasan atasan dan bimbingan langsung saat bekerja.

Hal yang terjadi di Bank DKI kantor cabang Surabaya mengenai kecerdasan emosional Berdasarkan hasil observasi peneliti dan wawancara dengan Bapak Denni Indra selaku Pimpinan Sie Back Office yang terjadi pada tanggal 10 Maret 2016 di Bank DKI kantor cabang Surabaya yaitu antar sesama karyawan terdapat kerjasama yang dilandasi semangat saling menghargai dan menghormati orang lain untuk mencapai hasil yang terbaik. Dibuktikan dari tidak adanya konflik antar karyawan karena selalu ada penyelesaian dan akan dibicarakan dengan baik jika terdapat keganjilan yang berhubungan dengan pekerjaan oleh karyawan tersebut.

Konflik yang ada dijelaskan seperti penyelesaian mengenai jadwal lembur antar karyawan yang terbilang bentrok dengan jadwal pribadi. Beberapa karyawan keberatan dengan jadwal lembur pada hari Sabtu-Minggu atau akhir bulan. Meskipun begitu karyawan dapat menyelesaikan jadwal lembur tersebut dengan baik seperti menukar jadwal sift lembur dengan karyawan lain tanpa ada permasalahan. Karyawan saling menerima dan membantu karyawan lain.

Jika diperhatikan perilaku karyawan telah sesuai dengan pedoman Bank DKI diantaranya senantiasa mendengar dan menghargai pendapat orang lain, tidak memaksakan kehendak pribadi, berpikir positif, memiliki tanggung jawab dan dedikasi terhadap pekerjannya ( Bank DKI, 2015).

Diketahui adanya kedekatakan antara karyawan dengan pimpinan bahkan perusahaan menerapkan sistem kekeluargaan dalam melaksanakan pekerjaan. Hal tersebut diberlakukan untuk kenyamanan karyawan bahkan perusahaan memberikan reward berupa bonus tahunan atau tunjangan kinerja untuk karyawan yang berprestasi. Terkadang diadakan rapat intern antara pimpinan Sie dan wakil pimpinan dengan pimpinan cabang untuk membahas promosi bagi karyawan berprestasi. Sehingga tidak ada keluhan mengenai permasalahan tunjangan, karyawan menerima dan memahami gaji yang diberikan perusahaan.

Karyawan juga dianggap puas terhadap pekerjannya jika dilihat dari 
pencapaian nasabah sesuai dengan yang ditargetkan perusahaan. Diantaranya perbedaan bagian pelayanan kredit konven yaitu melayani kredit nasabah hingga 500 juta rupiah dan mikro yaitu melayani kredit nasabah kurang dari 500 juta rupiah.

Bank DKI kantor cabang Surabaya berusaha untuk mempertahankan dan meningkatkan kepuasan kerja karyawannya dengan harapan memacu karyawan untuk lebih setia terhadap perusahaan, karyawan yang setia akan berusaha menghasilkan yang terbaik untuk perusahaan.

Menurut situs resmi Bank DKI menyebutkan jika karyawan perusahaan menjunjung tinggi nilai-nilai komitmen yang telah disepakati dan bertanggung jawab dengan sepenuh hati, diantaranya karyawan menindak lanjuti setiap masalah yang menjadi tanggung jawab mereka dan memastikan penyelesaian masalah hingga tuntas dan berkomitmen untuk mencintai pekerjaan dan citra Bank DKI. Bank DKI kantor cabang Surabaya menerapkan pedoman nilai KTPP DKI (Komitmen, Team work, Professional, Pelayanan, Displin, Kerja keras dan Integritas). Karyawan harus senantiasa menjaga komitmen yang ada dengan melaksanakan segala sesuatu yang diterapkan oleh perusahaan sesuai dengan perjanjian kerja.

Pembuktian karyawan menjaga komitmen pada Bank DKI kantor cabang Surabaya adalah dari sedikitnya bahkan hampir tidak pernah ada pelanggaran kebijakan perusahaan. Tidak ada paksaan pada karyawan dalam melaksanakan pekerjaan karena sudah seharusnya karyawan berusaha mengamalkan kesepakatan di awal perjanjian kerja.

\section{Teori Kecerdasan Emosional}

Menurut Salovey dan Meyer dalam Khalili (2011) definisi kecerdasan emosional adalah bagian dari kecerdasan sosial yang melibatkan kemampuan untuk memantau diri sendiri, perasaan dan emosi orang lain. Untuk membedakan, memberi informasi, dan membimbing pemikiran dan tindakan seseorang.

Menurut Davies dalam Seyal dan Afzaal (2013) menyatakan definisi kecerdasan emosional sebagai kemampuan yang baik dalam memahami emosi dalam diri sendiri dan membaca emosi orang lain.

\section{Teori Kepuasan Kerja}

Menurut Greenberg dan Baron dalam Sinambela (2012: 256) kepuasan kerja adalah sikap positif atau negatif yang dilakukan individu terhadap pekerjaannya.

Pendapat tersebut didukung oleh Davis dan Newstrom kepuasan kerja adalah seperangkat perasaan pegawai tentang menyenangkan atau tidaknya pekerjaan mereka (Sinambela, 2012:256).

\section{Teori Komitmen Organisasi}

Menurut Mowday et al, dalam Mohammed dan Elesweed (2013) mendefinisikan komitmen organisasi sebagai perilaku yang menghubungkan karyawan untuk organisasi.

Pendapat lain dari Mueller et al, komitmen organisasi adalah perasaan setia karyawan terhadap organisasinya (Karim dan Rehman: 2012). Komitmen organisasi menurut Yavuz dalam Karim dan Rehman (2012) sebagai salah satu 
tujuan utama dalam upaya organisasi memelihara keberadaan karyawan.

Dari teori-teori diatas dan tujuan penelitian maka berikut hipotesis yang akan diajukan dalam penelitian ini:

\begin{tabular}{|c|c|}
\hline $1=$ & $\begin{array}{l}\text { Diduga kecerdasan emosional } \\
\text { berpengaruh terhadap kepuasan } \\
\text { kerja pada Bank DKI Kantor } \\
\text { Cabang Surabaya. }\end{array}$ \\
\hline $\mathrm{H}_{2}=$ & $\begin{array}{l}\text { Diduga kepuasan kerja } \\
\text { berpengaruh terhadap komitmen } \\
\text { organisasi pada Bank DKI } \\
\text { Kantor Cabang Surabaya. }\end{array}$ \\
\hline $3=$ & $\begin{array}{l}\text { Diduga kecerdasan emosional } \\
\text { berpengaruh terhadap komitmen } \\
\text { organisasi pada Bank DKI } \\
\text { Kantor Cabang Surabaya. }\end{array}$ \\
\hline$=$ & $\begin{array}{l}\text { Diduga kepuasan kerja } \\
\text { memediasi pengaruh kecerdasan } \\
\text { emosional dengan komitmen }\end{array}$ \\
\hline
\end{tabular}

\section{METODE PENELITIAN}

Desain penelitian yang digunakan adalah kausalitas yang disusun untuk meneliti adanya hubungan sebab akibat antar variabel terdiri dari kecerdasan emosional, komitmen organisasi dan kepuasan kerja. Pendekatan kuantitatif digunakan dalam penelitian ini untuk menekankan hipotesis yang telah dirumuskan

Sumber data yang digunakan merupakan data primer yang di dapatkan dari penyebaran kuisioner langsung pada karyawan Bank DKI Kantor Cabang Surabaya.

Populasi dan sampel dari penelitian ini adalah 73 orang karyawan Bank DKI Kantor Cabang Surabaya dan angket yang kembali sebanyak 64 kuesioner karena kesibukan karyawan front liner yang selalu melayani setiap nasabahsepanjang waktu kerjanya.

Variabel yang digunakan dalam penelitian yaitu: Kecerdasan Emosional sebagai variabel independen dengan pengertian kemampuan untuk memotivasi diri sendiri dan bertahan menghadapi frustasi, mengendalikan dorongan hati dan tidak melebihlebihkan kesenangan, mengatur suasana hati dan menjaga agar beban stres tidak melumpuhkan kemampuan berpikir, berempati dan berdoa (Goleman, 2003: 45)

Indikator yang digunakan untuk mengukur kecerdasan emosional dalam penelitian mengacu penelitian Mohamadkhani dan lalardi (2012) mengutip Goleman menjelaskan kecerdasan emosional memiliki empat indikator, yaitu :

1) Kesadaran diri adalah kunci untuk mewujudkan kekuatan dan kelemahan yang terdapat pada diri sendiri. Kesadaran diri membantu individu dalam menangani reaksi emosional dengan baik;

2) Pengendalian diri, kemampuan untuk menjaga emosi negatif dan perilaku impulsif di bawah kontrol, tetap tenang dan tidak terusik bahkan dalam keadaan stres;

3) Kesadaran sosial, kemampuan untuk membaca atau merasakan emosi orang lain dan bagaimana dampaknya pada minat dan kepedulian orang lain terhadap individu tersebut;

4) Pengendalian hubungan, kemampuan untuk mempengaruhi, membimbing dan menangani emosi orang lain. 
(Cherniss dan Goleman, 2001: 3337).

Komitmen organisasi sebagai variabel dependen dengan pengertian ikatan emosional dan perasaan kasih antara karyawan terhadap organisasinya (Raza et al. 2014).

Indikator komitmen organisasi dalam penelitian sesuai dengan pendapat Stazyk et al. dalam Raza et al. (2014) mengemukakan sebagai berikut:

1) Komitmen afektif yaitu keyakinan kuat dan penerimaan tujuan organisasi dan nilai-nilai;

2) Komitmen normatif adalah kemauan untuk mengerahkan usaha atas nama organisasi;

3) Komitmen lanjutan merupakan timbulnya keinginan yang kuat untuk mempertahankan keanggotaan dalam organisasi.

Kepuasan kerja sebagai variabel intervening dengan pengertian keterkaitan karyawan terhadap apa yang telah dihasilkan oleh organisasinya sesuai dengan pendapat Farkas dan Tetrick dalam Aghdasi et al. (2011).

Indikator kepuasan kerja dalam penelitian mengacu pada gaji, promosi, rekan kerja, kepuasan terhadap atasan dan pekerjaan itu sendiri seperti yang dikemukakan oleh Smith dalam Aghdasi et al. (2011).

Teknik analisis data yang digunakan adalah Partial Least Square. Sebelum analisis Partial Least Square dilakukan pengujian validitas dan reliabilitas dengan tujuan mengetahui apakah item pernyataan tersebut valid dan reliabel, lalu dilakukan analisis deskriptif untuk memudahkan pembaca untuk mengetahui data yang disajikan.

\section{HASIL DAN PEEMBAHASAN}

Karakteristik Responden untuk menggambarkan masing-masing karakteristik karyawan yang didasarkan pada jenis kelamin, usia, pendidikan, dan masa kerja.

Tabel 4.1 Karakteristik Responden Berdasarkan Jenis Kelamin

\begin{tabular}{|c|c|c|c|}
\hline No. & Jenis Kelamin & Jumlah & Presentase \\
\hline 1. & Laki-Laki & 51 & $79,7 \%$ \\
\hline 2. & Perempuan & 13 & $20,3 \%$ \\
\hline \multicolumn{2}{|c|}{ Total } & 64 & 100 \\
\hline
\end{tabular}

Sumber: Data Penelitian, Diolah

Berdasarkan tabel 4.1 di atas, diketahui bahwa dari 64 responden karyawan dijadikan subjek penelitian, 51 orang $(79,7 \%)$ adalah responden berjenis kelamin laki-laki dan responden yang berjenis kelamin perempuan adalah 13 orang $(20,3 \%)$.

Tabel 4.2 Karakteristik Responden Berdasarkan Usia

\begin{tabular}{|c|c|c|c|}
\hline No. & Usia & Jumlah & Presentase \\
\hline 1. & $<30$ tahun & 48 & $75 \%$ \\
\hline
\end{tabular}


Riza Mutimma Auda - Pengaruh Kecerdasan Emosional Terhadap Komitmen ...

\begin{tabular}{|c|c|c|c|}
2. & $30-40$ tahun & 16 & $25 \%$ \\
\hline 3. & $41-50$ tahun & - & - \\
\hline 4. & $>51$ tahun & - & - \\
\hline \multicolumn{2}{|c|}{ Total } & 64 & $100 \%$ \\
\hline
\end{tabular}

Sumber: Data Penelitian, Diolah

Berdasarkan tabel di atas, jumlah responden berdasarkan usia dalam penelitian ini, usia $<30$ tahun sebanyak $75 \%$ usia $30-40$ tahun sebanyak $25 \%$. Dengan demikian, responden penelitian sebagian besar berusia $<30$ tahun.

Tabel 4.3Karakteristik Responden Berdasarkan Pendidikan

\begin{tabular}{|c|c|c|c|}
\hline No. & Pendidikan & Jumlah & Presentase \\
\hline 1. & SMA & - & - \\
\hline 2. & D3 & - & - \\
\hline 3. & S1 & 63 & $98,4 \%$ \\
\hline 4. & S2 & 1 & $1,6 \%$ \\
\hline \multicolumn{2}{|c|}{ Total } & 64 & $100 \%$ \\
\hline
\end{tabular}

Sumber: Data Penelitian, Diolah

Berdasarkan tabel 4.3, jumlah responden berdasarkan pendidikan tertinggi dalam penelitian ini adalah $\mathrm{S} 1$ $(98,4 \%)$ dan pendidikan S2 sebanyak
1,6\% karyawan. Dengan demikian, responden penelitian sebagian besar tingkat pendidikan $\mathrm{S} 1$.

Tabel 4.4

\section{Karakteristik Responden Berdasarkan Lama Bekerja}

\begin{tabular}{|c|c|c|c|}
\hline No. & Lama Bekerja & Jumlah & Presentasi \\
\hline 1. & $\leq 5$ tahun & 59 & 92,2 \\
\hline 2. & $>5-10$ tahun & 3 & 4,7 \\
\hline 3. & $>10-15$ tahun & 2 & 3,1 \\
\hline 4. & $>15-20$ tahun & - & - \\
\hline 5. & $>20$ tahun & - & - \\
\hline \multicolumn{2}{|c|}{ Total } & 64 & $100 \%$ \\
\hline
\end{tabular}

Sumber: Data Penelitian, Diolah

Berdasarkan tabel 4.4 di atas, jumlah responden berdasarkan lama bekerja dalam penelitian ini, lama bekerja $<5$ tahun sebanyak 60 orang $(92,2 \%)$, lama bekerja $>5-10$ tahun sebanyak 2 orang $(4,7 \%)$, lama bekerja $>10-15$ tahun $(3,1 \%)$. Dengan demikian, responden penelitian sebagian besar lama bekerja di perusahaan selama $\leq 5$ tahun.

\section{Hasil Statistik Rata-Rata}

Kecerdasan Emosional 
Hasil statistik rata - rata kecerdasan emosional menunjukkan bahwa penerapan kesadaran diri karyawan Bank DKI Kantor Cabang Surabaya meliputi yakin pada kemampuan diri, pemahaman emosi pada diri sendiri dan orang lain, serta kemampuan menghadapi keadaan di sekitar dalam ketegori tinggi. Hal tersebut dibuktikan dari nilai rata-rata sebesar 4,28 \% dengan keterangan 91 pernyataan sangat setuju dan 147 pernyataan setuju, sedangkan hanya sebagian kecil responden menjawab netral, tidak setuju dan sangat tidak setuju.

Kemudian untuk hasil indikator pengendalian hubungan memiliki nilai rata - rata yang sama tingginya dengan kesadaran diri sebesar 4,26\%. Hal tersebut dibuktikan dari 89 pernyataan sangat setuju dan 144 pernyataan setuju, sedangkan jawaban netral, tidak setuju dan sangat tidak setuju hanya sebagian kecil responden yang menjawab.

Kedua indikator lain dalam kecerdasan emosional yaitu pengendalian diri dan kesadaran sosial berkategori tinggi dengan nilai 4,14 dan 4,10 berturut- turut.

Kepuasan Kerja

Hasil statistik rata - rata kepuasan kerja menunjukkan bahwa kepuasan karyawan terhadap rekan kerjanyanya dalam kategori tinggi. Nilai rata - ratanya adalah 4,31 dengan 34 pernyataan setuju, 25 pernyataan sangat setuju, 5 pernyataan netral dan tidak terdapat pernyataan tidak setuju maupun sangat tidak setuju.

Kemudian kepuasan terhadap pekerjaan itu sendiri memiliki nilai rata - rata tidak jauh berbeda sama tinggi sebesar 4,13. Keterangannya yaitu 18 pernyataan setuju, 22 pernyataan sangat setuju dan 14 pernyataan netral. Dalam indikator tersebut tidak terdapat pernyataan tidak setuju maupun sangat tidak setuju.

Indikator selanjutnya memiliki nilai yang sama tinggi berturut - turut yaitu kepuasan terhadap gaji, promosi dan atasan dengan nilai rata - rata 3,98, 3,92, 3,88.

Komitmen Organisasi

Hasil statistik rata - rata komitmen organisasi menunjukkan bahwa indikator komitmen lanjutan dalam kategori tertinggi dengan nilai rata - rata 4,00.

Kemudian rata - rata tertinggi selanjutnya adalah komitmen afektif dengan nilai 3,94. Nilai dari komitmen normatif dalam kategori yang tinggi dengan rata - rata sebesar 3,88.

Uji Validitas

Uji validitas digunakan untuk menentukan apakah indikator dinyatakan valid dan dapat mengukur variabel yang diteliti. Uji validitas dilakukan dengan bantuan software smartPLS 3.0.

Tabel 4.9 Outer Loading dari Variabel Kecerdasan Emosional

\begin{tabular}{|c|c|c|}
\hline Item & Outer Loading & Keterangan \\
\hline X1.2 & 0,611 & Valid \\
\hline X1.3 & 0,576 & Valid \\
\hline X1.4 & 0,511 & Valid \\
\hline X2.1 & 0,633 & Valid \\
\hline X2.2 & 0,671 & Valid \\
\hline
\end{tabular}




\begin{tabular}{|c|c|c|} 
X2.3 & 0,634 & Valid \\
\hline X2.4 & 0,505 & Valid \\
\hline X3.1 & 0,647 & Valid \\
\hline X3.2 & 0,553 & Valid \\
\hline X4.1 & 0,678 & Valid \\
\hline X4.2 & 0,526 & Valid \\
\hline X4.3 & 0,636 & Valid \\
\hline X4.4 & 0,576 & Valid \\
\hline
\end{tabular}

Sumber: Output Smart PLS 3.0, 2016

Dari tabel 4.9 menunjukkan bahwa pernyataan kecerdasan emosional lebih outer loading dari masing-masing item besar dari 0,50.

Tabel 4.10 Outer Loading dari Variabel Kepuasan Kerja

\begin{tabular}{|c|c|c|}
\hline Item & Outer Loading & Keterangan \\
\hline Z1 & 0,867 & Valid \\
\hline Z2 & 0,874 & Valid \\
\hline Z3 & 0,564 & Valid \\
\hline Z4 & 0,833 & Valid \\
\hline Z5 & 0,829 & Valid \\
\hline
\end{tabular}

Sumber: Output Smart PLS 3.0, 2016

Dari tabel 4.10 menunjukkan outer loading dari masing-masing item pernyataan dari indikator kepuasan kerja lebih besar dari 0,50.

Tabel 4.11 Outer Loading dari Variabel Komitmen Organisasi

\begin{tabular}{|c|c|c|}
\hline Item & Outer Loading & Keterangan \\
\hline Y1.1 & 0,789 & Valid \\
\hline Y1.2 & 0,866 & Valid \\
\hline Y2.1 & 0,742 & Valid \\
\hline Y2.2 & 0,852 & Valid \\
\hline Y3.1 & 0,734 & Valid \\
\hline Y3.2 & 0,794 & Valid \\
\hline
\end{tabular}

Sumber: Data PLS 3.0, 2016

Dari tabel 4.11 menunjukkan outer loading dari masing masing item pernyataan komitmen organisasi lebih besar dari 0,50.

Berdasarkan tabel 4.9, 4.10 dan 4.11 tampak bahwa semua outer loading di atas 0,50. Hal ini dapat disimpulkan bahwa variabel-variabel di atas mempunyai convergent validity yang baik.
Uji Reliabilitas

Composite reliability ini digunakan untuk menguji nilai reliabilitas dari setiap blok indikator yang mengukur sebuah konstruk. Konstruk dinyatakan reliable jika nilai composite reliability di atas 0,70. Berikut ini adalah hasil perhitungan composite reliability pada tiap variabel.

Tabel 4.12 Composite Reliability Variabel

\begin{tabular}{|c|c|}
\hline Variabel & Composite Reliability \\
\hline Kecerdasan Emosional & 0,878
\end{tabular}




\begin{tabular}{|c|c|}
\hline Kepuasan Kerja & 0,898 \\
\hline Komitmen Organisasi & 0,913 \\
\hline
\end{tabular}

Sumber: Output PLS 3.0, 2016

Berdasarkan tabel 4.13 terlihat nilai composite reliability untuk semua variabel lebih besar dari 0,70. Dengan demikian model variabel tersebut telah memenuhi composite reliability atau memiliki reliabilitas yang baik.

Hasil R-Square (Inner Model)
Berikut ini merupakan hasil dari pengaruh kecerdasan emosional terhadap komitmen organisasi melalui kepuasaan kerja sebagai variabel mediasi pada Bank DKI Kantor Cabang Surabaya, dihasilkan nilai koefisien determinan (R-Square).

Tabel 4.14 Nilai R-Square Model

\begin{tabular}{|c|c|}
\hline Variabel & R-Square \\
\hline Kecerdasan Emosional & \\
\hline Kepuasan Kerja & 0,506 \\
\hline Komitmen Organisasi & 0,778 \\
\hline
\end{tabular}

Sumber: Output PLS 3.0, 2016

Pada tabel 4.14 di atas, model pengaruh kecerdasan emosional terhadap kepuasan kerja memberikan nilai $R$-Square sebesar 0,506 yang dapat di interpretasikan bahwa variabel konstruk kepuasan kerja yang dapat dijelaskan oleh variabel kecerdasan emosional sebesar $50,6 \%$ sedangkan faktor-faktor lain dalam kecerdasan emosional yang tidak terdapat dalam penelitian mampu menjelaskan kepuasan kerja pada Bank DKI Kantor Cabang Surabaya sebesar 49,4\%.

Pada tabel 4.14 juga menunjukkan model pengaruh kecerdasan emosional terhadap komitmen organisasi memberikan pengaruh $R$-square sebesar $77,8 \%$ yang dapat diinterpretasikan bahwa variabel konstruk komitmen organisasi dapat dijelaskan oleh variabel kecerdasan emosional sebesar 77,8\% sedangkan faktor-faktor lain dalam kecerdasan emosional yang tidak terdapat dalam penelitian mampu menjelaskan komitmen organisasi pada Bank DKI Kantor Cabang Surabaya sebesar 22,2\%.

Hasil Uji T (Signifikansi)

Tahapan ini bertujuan untuk mengetahui ada atau tidaknya pengaruh yang signifikan antar variabel. Suatu pengaruh antar variabel dikatakan signifikan apabila nilai $t$ hitung lebih besar dari 1,96 atau $\mathrm{P}$ value lebih kecil dari 0,05 .

Tabel 4.15 Hasil Path Coefficients

\begin{tabular}{|l|l|c|c|c|}
\hline $\begin{array}{c}\text { Hubungan } \\
\text { Antar } \\
\text { Variabel }\end{array}$ & $\begin{array}{c}\text { Original } \\
\text { Sample }\end{array}$ & $\begin{array}{c}T- \\
\text { Statistics }\end{array}$ & Keterangan & Kesimpulan \\
\hline $\begin{array}{l}\text { Kecerdasan } \\
\text { Emosional } \rightarrow \\
\text { Kepuasan } \\
\text { Kerja }\end{array}$ & 0,711 & 12,812 & $\begin{array}{c}\geq 1,96 \\
\text { (signifikan) }\end{array}$ & $\begin{array}{c}\text { Hipotesis } \\
\text { Diterima }\end{array}$ \\
\hline
\end{tabular}




\begin{tabular}{|l|c|c|c|c|}
$\begin{array}{l}\text { Kecerdasan } \\
\text { Emosional } \\
\text { Komitmen } \\
\text { Organisasi }\end{array}$ & 0,233 & 2,652 & $\begin{array}{c}\geq 1,96 \\
\text { (signifikan) }\end{array}$ & $\begin{array}{c}\text { Hipotesis } \\
\text { Diterima }\end{array}$ \\
\hline $\begin{array}{l}\text { Kepuasan } \\
\text { Kerja } \rightarrow \\
\begin{array}{l}\text { Komitmen } \\
\text { Organisasi }\end{array}\end{array}$ & 0,702 & 8,289 & $\begin{array}{c}\geq 1,96 \\
\text { (signifikan) }\end{array}$ & $\begin{array}{c}\text { Hipotesis } \\
\text { Diterima }\end{array}$ \\
\hline
\end{tabular}

Sumber: Output PLS 3.0, 2016

Berdasarkan tabel 4.15 dapat dijabarkan pengujian antar variabel sebagai berikut:

Besarnya nilai t-statistics pengaruh kecerdasan emosional terhadap kepuasan kerja sebesar 12,812 lebih besar dari 1,96. Hal ini menunjukkan adanya pengaruh yang signifikan pada variabel kecerdasan emosional terhadap kepuasan kerja. Sedangkan koefisien estimate sebesar 0,711. Koefisien tersebut bertanda positif yang apabila semakin meningkat kecerdasan emosional maka kepuasan kerja semakin meningkat pula, begitu juga sebaliknya.

Besarnya nilai $t$-statistics pengaruh kecerdasan emosional terhadap komitmen organisasi sebesar 2,652 lebih besar dari 1,96. Hal ini menunjukkan adanya pengaruh signifikan pada variabel kecerdasan emosional terhadap komitmen organisasi. Sedangkan koefisien estimate sebesar 0,233. Koefisien tersebut bertanda positif yang apabila kecerdasan emosional meningkat maka komitmen organisasi semakin meningkat pula, begitu juga sebaliknya.

Besarnya nilai t-statistics pengaruh kepuasan kerja terhadap komitmen organisasi sebesar 8,289 lebih besar dari 1,96. Hal ini menunjukkan adanya pengaruh signifikan pada variabel kepuasan kerja terhadap komitmen organisasi. Sedangkan koefisien estimate sebesar 0,702. Koefisien tersebut bertanda positif yang apabila kepuasan kerja meningkat maka komitmen organisasi semakin meningkat pula, begitu juga sebaliknya.

Dalam penelitian ini, dapat dilihat besarnya koefisien pengaruh langsung dan tidak langsung antar variabel dalam tabel berikut:

Tabel 4.16 Pengaruh Langsung dan Tidak Langsung

\begin{tabular}{|l|c|c|}
\hline \multicolumn{1}{|c|}{ Path } & $\begin{array}{c}\text { Koefisien } \\
\text { Pengaruh }\end{array}$ & Kesimpulan \\
\hline $\begin{array}{l}\text { Kecerdasan } \\
\text { Emosional } \rightarrow \\
\text { Komitmen Organisasi }\end{array}$ & 0,233 & \\
\hline $\begin{array}{l}\text { Kecerdasan } \\
\text { Emosional } \rightarrow \rightarrow \rightarrow\end{array}$ & $0,711 \times 0,702=$ & Hipotesis
\end{tabular}




\begin{tabular}{|l|l|l|}
$\begin{array}{l}\text { Kepuasan Kerja } \\
\text { Komitmen Organisasi }\end{array}$ & 0,499 & Diterima \\
\hline
\end{tabular}

Sumber: Output PLS 3.0, 2016

Dari tabel 4.16 dapat diketahui bahwa besarnya koefisien pengaruh langsung kecerdasan emosional terhadap komitmen organisasi lebih kecil dari pada pengaruh tidak langsung kecerdasan emosional terhadap komitmen organisasi melalui kepuasan kerja pada karyawan Bank DKI Kantor Cabang Surabaya. Sehingga menunjukkan bahwa kepuasan kerja merupakan mediasi dari hubungan pengaruh kecerdasan emosional terhadap komitmen organisasi.

Pengaruh Kecerdasan Emosional Terhadap Kepuasan Kerja

Berdasarkan hasil pengujian, peneliti menemukan bahwa kecerdasan emosional terhadap kepuasan kerja karyawan Bank DKI Kantor Cabang Surabaya berpengaruh positif dan signifikan, sehingga H1 diterima. Hasil penelitian ini memperkuat hasil penelitian Fatima et al. (2010), Sandhu (2015) yang menyatakan bahwa kecerdasan emosional berdampak signifikan dan positif terhadap kepuasan kerja. Hal tersebut didukung dengan deskriptif responden untuk variabel kecerdasan emosional termasuk dalam kategori tinggi dalam Three Box Metod dengan nilai rata-rata 4,19 dan kepuasan kerja 4,04.

Kesadaran diri memiliki nilai ratarata tertinggi karena menurut Bapak Denni Indra selaku Pimpinan Sie Back Office karyawan sangat baik dalam mengendalikan emosi diri terlihat dari hampir tidak adanya konflik antar karyawan bahkan selalu diselesaikan sebelum timbul permasalahan seperti karyawan memahami kesalahannya dan berusaha memperbaiki jika mendapat kritik dari rekan kerja yang lain atas pekerjaan yang harus diperbaiki.

Untuk kesadaran sosial memiliki nilai tinggi dengan rata-rata kecil dibandingkan indikator lain menurut Bapak Denni dikarenakan adanya perbedaan pikiran antar karyawan yang satu dengan yang lain dalam melaksanakan pekerjaan dan jam istirahat yang tidak banyak digunakan untuk bercerita mengenai permasalahan pribadi mengingat Bank adalah perusahaan jasa dengan keterbatasan waktu istirahat yang harus benar-benar digunakan untuk kebutuhan pribadi. Sedangkan hal tersebut dapat ditingkatkan dengan kegiatan konseling namun waktu sangat terbatas hanya dilakukan satu minggu sekali setiap hari Rabu dengan waktu dua kali dalam satu hari. Pagi hari membahas briefing dan malam hari melakukan pembahasan kinerja per divisi.

Peningkatan kepuasan kerja karyawan disebabkan dari nilai rata-rata tertinggi adalah kepuasan terhadap rekan kerja sebesar 4,31. Dapat disebutkan bahwa kemampuan karyawan dalam mengendalikan emosi terhadap karyawan lain berdampak pada kepuasan kerjanya.

Maka dapat disimpulkan karyawan Bank DKI menerapkan kecerdasan emosional diri dengan baik sehingga 
tercipta kepuasan kerja. Karena adanya kemampuan karyawan dalam memahami dan membaca emosi orang lain baik sesama rekan kerja maupun atasannya. Serta perannya dalam menghadapi kesulitan di sekitarnya meningkatkan kepuasan kerja karyawan terhadap perusahaan.

\section{Pengaruh Kepuasan Kerja Terhadap Komitmen Organisasi}

Sesuai dengan pengujian hipotesis pada penelitian ini diperoleh hasil bahwa kepuasan kerja terhadap komitmen organisasi berpengaruh positif dan signifikan, yaitu apabila semakin tinggi kepuasan kerja karyawan maka akan semakin meningkat pula komitmen organisasi. Sehingga $\mathrm{H} 2$ diterima. Hasil penelitian ini mendukung penelitian Tiur A. (2013), Najafi et al. (2011), dan Mangkunegara et al. (2015).

Penelitian ini menunjukkan bahwa kepuasan kerja yang ada pada karyawan Bank DKI Kantor Cabang Surabaya seperti kepuasan pada rekan kerja memiliki skor tinggi yaitu 4,31. Menurut Bapak Denni Indra hal tersebut dikarenakan terlihat dari kuatnya ikatan antar rekan se divisi misalnya pekerjaan tim yang terselesaikan sesuai deadline, antar karyawan saling memback up pekerjaan dalam divisinya dan kegiatankegiatan berkumpul bersama di luar jam kantor lebih sering dilakukan oleh antar rekan satu divisi tersebut.

Kepuasan terhadap atasan memiliki rata-rata nilai tinggi namun lebih kecil dibandingkan indikator lain karena disebutkan oleh Bapak Denni dan karyawannya bahwa atasan memiliki sifat yang perfectionis. Atasan selalu menginginkan pekerjaan dapat dilaksanakan cepat tuntas dan tetap jika tidak sesuai dengan batas waktu tentunya karyawan akan ditegur.

Hal tersebut sesungguhnya hal yang baik dan lumrah. Kurangnya komunikasi dan waktu bertatap muka antar karyawan dengan atasan menjadi kendalanya karena antar karyawan dengan atasan kurang mengenal masing-masing pribadi dengan baik. Sedangkan kegiatan gathering yang melibatkan seluruh karyawan Bank DKI baik itu atasan, staff maupun tenaga kerja pembantu biasanya hanya dilakukan satu tahun sekali dan menunggu perayaan HUT Bank DKI pada bulan April yang biasanya kegiatan tersebut harus memakan waktu dalam persiapannya, juga harus merencanakan pengalokasian dana yang tidak sedikit karena gathering biasanya juga melibatkan keluarga para karyawan.

Hasil penelitian menunjukkan persamaan dengan fenomena yang ada di perusahaan sesuai dengan hasil wawancara oleh Bapak Denni Indra selaku Pimsie Back Office bahwa tidak ada keluhan mengenai permasalahan tunjangan, karyawan menerima dan memahami gaji yang diberikan perusahaan. Karyawan juga dianggap puas terhadap pekerjannya jika dilihat dari pencapaian nasabah sesuai dengan yang ditargetkan perusahaan.

Karyawan yang sudah merasa puas pada pekerjaannya dan perusahaannya akan berusaha menerapkan dan menjaga komitmen di organisasinya. Dapat dilihat dari karyawan dapat melaksanakan pekerjannya sesuai 
komitmen awal dengan perusahaan tanpa adanya paksaan karena tingginya nilai kepuasan kerja di Bank DKI Kantor Cabang Surabaya.

\section{Pengaruh Kecerdasan Emosional} Terhadap Komitmen Organisasi

Berdasarkan hasil pengujian, peneliti menemukan bahwa pengaruh kecerdasan emosional terhadap komitmen organisasi berpengaruh positif dan signifikan, sehingga H3 diterima. Hasil penelitian ini memperkuat hasil penelitian Atmaja et al. (2015), Raza et al. (2014), Aisyah A.R (2012) yang menyatakan bahwa kecerdasan emosional berpengaruh langsung dan positif.

Dilihat dari skor rata-rata indikator komitmen organisasi ke tiga nya memiliki rata-rata tinggi dengan komitmen lanjutan memiliki nilai tertinggi yaitu sebesar 4,00. Menurut Bapak Denni Indra komitmen lanjutan begitu diterapkan oleh karyawan Bank DKI dari tidak adanya keluhan mengenai pekerjaan dan tugas yang diberikan karena karyawan senantiasa melaksanakan pekerjaan tersebut sesuai dengan keinginan dan keahliannnya.

Komitmen normatif memiliki ratarata tinggi namun lebih kecil dibandingkan kedua indikator lain karena menurut pengakuan dari karyawan hal tersebut dikarenakan banyak pengorbanan waktu untuk kepentingan pribadi yang diberikan pada perusahaan. Terlihat dari karyawan yang melakukan lembur kerja karena tidak dapat menyelesaikan pekerjaannya biasanya pada waktu tutup buku seperti akhir pekan, akhir bulan dan akhir tahun.
Sesungguhnya pekerjaan tersebut merupakan kewajiban bagi karyawan itu sendiri karena sesuai dengan komitmen di perjanjian kerja. Hal tersebut dikendalikan oleh Bank DKI melalui pelatihan dan pengembangan karyawan yang berkomitmen sesuai dengan pedoman perusahaan KTPP DKI (Komitmen, Team work, Professional, Pelayanan, Displin, Kerja keras dan Integritas) namun hanya dalam momen tertentu dengan mengikut sertakan perwakilan divisinya.

Hasil penelitian sudah sesuai dengan keadaan yang terdapat pada perusahaan bahwa kecerdasan emosional karyawan Bank DKI Kantor Cabang Surabaya cukup tinggi bahwa antar sesama karyawan terdapat kerjasama yang dilandasi semangat saling menghargai dan menghormati orang lain untuk mencapai hasil yang terbaik.

Hampir tidak adanya konflik yang timbul antar karyawan meningkatkan komitmen terhadap organisasinya. Karyawan senantiasa mengendalikan emosi diri demi menjaga komitmen yang telah diterapkan oleh Bank DKI Kantor Cabang Surabaya.

\section{Pengaruh Kecerdasan Emosional terhadap Komitmen Organisasi Melalui Kepuasan Kerja}

Hasil Penelitian pengaruh tidak langsung kecerdasan emosional terhadap komitmen organisasi melalui kepuasan kerja menunjukkan nilai koefisien pengaruh yang lebih besar yaitu 0,499 dari pengaruh langsung kecerdasan emosional terhadap komitmen organisasi yaitu sebesar 0,233 . 
Sehingga kepuasan kerja merupakan mediasi pengaruh kecerdasan emosional terhadap terhadap komitmen organisasi. Hasil peneltian ini memperkuat penelitian Aghdasi et al, (2011) bahwa kepuasan kerja memediasi pengaruh antara kecerdasan emosional terhadap komitmen organisasi. Oleh karena itu penelitian ini menunjukkan bahwa $\mathrm{H} 4$ diterima.

Karyawan memiliki kesadaran diri, mampu mengendalikan hubungan dengan karyawan lain, mampu mengendalikan diri dan kesadaran sosial. Interaksi yang positif menjadikan karyawan nyaman dalam bekerja seperti dapat menyelesaikan permasalahan deadline pekerjaan yang seharusnya diselesaikan oleh satu karyawan saja namun akibat kecerdasan emosional yang tinggi mampu membuat rekan kerja saling membantu untuk meningkatkan kepuasan kerja karyawan.

Meningkatnya kepuasan terhadap rekan kerja menjadikan karyawan berusaha untuk menerapkan komitmen pada perusahaan. Karyawan menganggap bahwa permasalahan perusahaan merupakan permasalahan pribadi yang sering terjadi misalnya selisih rekonsiliasi perusahaan karyawan berusaha menyelesaikan selisih tersebut dengan mencari sumber selisih kas karena laporan perusahaan harus dilaporkan secara berkala pada Bank Indonesia. Bila terjadi rekonsiliasi bahkan karyawan rela mengorbankan jam kerja demi menyelesaikan permasalahan perusahaan.

Dengan demikian nilai komitmen organisasi cukup tinggi apabila karyawan memiliki kecerdasan emosional yang tinggi dan mengabitkan naiknya nilai kepuasan kerja.

\section{KESIMPULAN}

Pengaruh Kecerdasan Emosional Terhadap Kepuasan Kerja

Berdasarkan hasil pengujian, peneliti menemukan bahwa kecerdasan emosional terhadap kepuasan kerja karyawan Bank DKI Kantor Cabang Surabaya berpengaruh positif dan signifikan, sehingga $\mathrm{H} 1$ diterima. Hasil penelitian ini memperkuat hasil penelitian Fatima et al. (2010), Ramesh Sandhu (2015) yang menyatakan bahwa kecerdasan emosional berdampak signifikan dan positif terhadap kepuasan kerja.

Karyawan Bank DKI menerapkan kecerdasan emosional diri dengan baik sehingga tercipta kepuasan kerja. Karena adanya kemampuan karyawan dalam memahami dan membaca emosi orang lain baik sesama rekan kerja maupun atasannya. Serta perannya dalam menghadapi kesulitan di sekitarnya meningkatkan kepuasan kerja karyawan terhadap perusahaan.

Pengaruh Kepuasan Kerja Terhadap Komitmen Organisasi

Sesuai dengan pengujian hipotesis pada penelitian ini diperoleh hasil bahwa kepuasan kerja terhadap komitmen organisasi berpengaruh positif dan signifikan, yaitu apabila semakin tinggi kepuasan kerja karyawan maka akan semakin meningkat pula komitmen organisasi. Sehingga $\mathrm{H} 2$ diterima. Hasil penelitian ini mendukung penelitian Tiur A. 
(2013), Najafi et al. (2011), dan Mangkunegara et al. (2015).

Karyawan yang sudah merasa
puas pada pekerjaannya dan perusahaannya akan berusaha menerapkan dan menjaga komitmen di organisasinya. Dapat dilihat dari karyawan dapat melaksanakan pekerjannya sesuai komitmen awal dengan perusahaan tanpa adanya paksaan karena tingginya nilai kepuasan kerja di Bank DKI Kantor Cabang Surabaya.

Pengaruh Kecerdasan Emosional Terhadap Komitmen Organisasi

Berdasarkan hasil pengujian, peneliti menemukan bahwa pengaruh kecerdasan emosional terhadap komitmen organisasi berpengaruh positif dan signifikan, sehingga $\mathrm{H} 3$ diterima. Hasil penelitian ini memperkuat hasil penelitian Atmaja et al. (2015), Raza et al. (2014), Aisyah A.R (2012) yang menyatakan bahwa kecerdasan emosional berpengaruh langsung dan positif.

Hasil penelitian sudah sesuai dengan keadaan yang terdapat pada perusahaan bahwa kecerdasan emosional karyawan Bank DKI Kantor Cabang Surabaya cukup tinggi bahwa antar sesama karyawan terdapat kerjasama yang dilandasi semangat saling menghargai dan menghormati orang lain untuk mencapai hasil yang terbaik.

Hampir tidak adanya konflik yang timbul antar karyawan meningkatkan komitmen terhadap organisasinya. Karyawan senantiasa mengendalikan emosi diri demi menjaga komitmen yang telah diterapkan oleh Bank DKI Kantor Cabang Surabaya.

\section{Pengaruh Kecerdasan Emosional terhadap Komitmen Organisasi Melalui Kepuasan Kerja}

Hasil Penelitian pengaruh tidak langsung kecerdasan emosional terhadap komitmen organisasi melalui kepuasan kerja menunjukkan nilai koefisien pengaruh yang lebih besar yaitu 0,499 dari pengaruh langsung kecerdasan emosional terhadap komitmen organisasi yaitu sebesar 0,233 . Sehingga kepuasan kerja merupakan mediasi pengaruh kecerdasan emosional terhadap terhadap komitmen organisasi. Hasil peneltian ini memperkuat penelitian Aghdasi et al, (2011) bahwa kepuasan kerja memediasi pengaruh antara kecerdasan emosional terhadap komitmen organisasi. Oleh karena itu penelitian ini menunjukkan bahwa $\mathrm{H} 4$ diterima.

Dengan demikian nilai komitmen organisasi cukup tinggi apabila karyawan memiliki kecerdasan emosional yang tinggi dan mengabatkan naiknya nilai kepuasan kerja.

\section{SARAN}

1. Dilihat dari skor rata-rata indikator kecerdasan emosional meskipun dengan kategori tinggi dengan nilai kecil dibandingkan indikator lain adalah indikator kesadaran sosial. Untuk meningkatkan nilai kesadaran sosial peneliti menyarankan lebih diperbanyak frekuensi konseling yang sebelumnya satu minggu sekali diperbanyak menjadi dua kali dalam satu minggu namun dengan 
menggabungkan antara briefing untuk esok hari dan pembahasan kerja hari tersebut yang sebelumnya dilakukan dengan waktu terpisah sebelum bekerja dan selesai jam kerja dengan tujuan karyawan tidak jenuh mendengarkan masukan,kritik dan saran dari karyawan lain. Sebaiknya tidak memakan banyak waktu dilakukan secara santai dan kekeluargaan sepulang kantor supaya karyawan tidak merasa lelah.

2. Dilihat dari skor rata-rata indikator kepuasan kerja meskipun dengan kategori tinggi dengan nilai kecil dibandingkan indikator lain adalah kepuasan terhadap atasan. Untuk meningkatkan nilai kepuasan terhadap atasan lebih sering mengagendakan kegiatan ramah tamah (gathering) yang biasanya hanya dilakukan satu tahun sekali. Tidak hanya dalam perayaan HUT Bank DKI saja yang harus direncanakan di tengah kesibukan waktu kerja karyawan sebaiknya diagendakan di kesempatan lain seperti merencanakan acara kegiatan sosial jika terkait pengalokasian dana sebaiknya dilakukan secara sederhana supaya lebih mudah terealisasi. Hal tersebut dilakukan untuk memperbanyak waktu sharing dan dilakukan untuk membantu karyawan lebih mengenal karakter atasan dengan baik dan memperkuat hubungan kerja karyawan dan atasan.

3. Dilihat dari skor rata-rata indikator komitmen organisasi meskipun dengan kategori tinggi dengan nilai kecil dibandingkan indikator lain adalah komitmen normatif. Untuk itu disarankan perusahaan senantiasa mengajak karyawan dengan cara yang tepat supaya karyawan dapat bekerja dengan sungguh-sungguh dan merasa memiliki kewajiban atas komitmennya terhadap organisasi. Melakukan pelatihan dan pengembangan tidak hanya dilakukan dan diwakilkan oleh satu karyawan saja di setiap bagian namun secara merata dan bergantian untuk pembentukan karakter karyawan yang bekerja demi kemajuan perusahaan.

4. Hasil dari penelitian menyebutkan pengaruh langsung antara kecerdasan emosional terhadap komitmen organisasi memiliki nilai positif namun lebih rendah dibandingkan pengaruh tidak langsung antara kecerdasan emosional terhadap komitmen organisasi melalui kepuasan kerja. Sesungguhnya kecerdasan emosional dalam diri setiap karyawan sangat dibutuhkan untuk meningkatkan penerapan komitmen organisasi yang telah ada oleh karenanya disarankan perusahaan lebih banyak lagi menambah frekuensi kegiatan untuk berkumpul dan membicarakan permasalahan pekerjaan antar karyawan baik itu atasan atau rekan kerja seperti rapat seluruh karyawan . Kegiatan tersebut sebaiknya juga ditujukan untuk menghasilkan kesepakatan yang 
diusulkan dan disepakati oleh semua karyawan untuk kemajuan perusahaan. Tujuannya adalah untuk saling menghargai mendengarkan yang orang lain katakan dan mengajak karyawan untuk ikut terkait dalam setiap urusan di perusahaan dalam meningkatkan komitmen organisasi Bank DKI Kantor Cabang Surabaya.

\section{REFERENSI}

Aghdasi Samaneh, Kiamanseh Ali Reza, Ebrahim Abdolrohim Naveh, 2011. Emotional Intelligence and Organizational Commitment:Testing the Mediatory Role of Occupational Stress and Job Satisfaction. Iran: International Conference on Education and Educational Psychology, 1965-1976.

Aisyah A.R, 2012. The Influence of Self-Efficacy, Emotional Intelligence, Innovativeness and Organizational Commitment on the Performance of the Echelon III Employees in Palembang. International Journal of Science and Research, 3(12), 223-229.

Atmaja surya Mulyana, Hardienata Soewarto, Sunaryo Widodo, 2015. The Effect of Organizational Culture, Emotional Intelligence and Training Effectiveness to Organizational Commitment. Indonesia: International Journal of Managerial Studies and Research, 3(4), 40-45.

Bank DKI, 2015. Profil Bank DKI. http://www.bankdki.co.id/id/corpo rate-website/profil-bank-dki.

Diakses tanggal 04 Ferbuari 2016. Cherniss, Cary dan Goleman, Daniel, 2001. The emotionally Intelligent Workplace: How To Select For, Measure, And Improve Emotional Intelligence In Individuals, Groups, And Organizations. First Edition, United States: JosseyBass.

Ezzatabadi Mohammad Ranjbar, Bahrami Mohammad Amin, Hadizadeh Farzaneh, Arab Masoomeh, Nasiri Soheyla, Tehrani Golamreza Ahmadi, 2013. The nurses' emotional intelligence impact on the quality of hospital services. Iran: Sudanese Journal of Public Health, 158-163.

Farzeen Maria, Ahmad Aqeel, Anwar Naveed, 2015. Relationship among Job Satisfaction, Attitude towards work And Organizational Commitment. Pakistan: Journal of Management Info, 5(1), 84-96.

Fatima Afsheen, Imran Rabia, Zaheer Arshad, 2010. Emotional Intelligence and Job Satisfaction: Mediated by Transformational Leadership. Pakistan: World Applied Science Journal, 10(6), 612-620.

Ghoreishi FS, Zahirrodine AR, Assarian F, Moozavi SGA, Mehrizi MZZ, 2014. Evaluation of Emotional Intelligence and Job Satisfaction in Employees of Kashan Hospitals, Iran: Nurs Midwifery Study, 3(1), 1-6.

Goleman, Daniel, 2003. Kecerdasan Emosional, terj. T. Hermaya. 
Cetakan XIII, Jakarta: Gramedia Pustaka Utama.

Karim, Faisal dan Rehman Omar, 2012. Impact of Job Satisfaction, Perceived Organizational Justice and Employee Empowerment on Organizational Commitment in Semi-Government Organizations of Pakistan. Journal of Business Studies Quarterly, 3(4), 92-104.

Khalili, Ashkan, 2011. Examining the Relevance of Emotional Intelligence and Organizational Commitment among Employees of Small and Medium Enterprise in Private Sector. Malaysia: International Journal of Business and Management, 6(12), 180-194.

Kishan R, Anu dan Sebastian, Preethi, 2014. An Analysis of Emotional Intelligence Organizational Commitment and Absenteeism Among The Employees of A Mattress Company, India. International Journal of Emerging Technology and Advanced Engineering, 4 (5), 743-747.

Madi Mohammed, Abu Jarad Ismail, Alqahtani Ali H.M, 2012. Employees' Perception and Organizational Commitment: A Study on the Banking Sector in Gaza, Palestine. International Journal of Business and Social Science, 3(16), 299-312.

Mangkunegara, Anwar Prabu dan Octorend, Tinton Rumbungan, 2015. Effect of Work Discipline, Work Motivation and Job Satisfaction on Employee Organizational Commitment in the Company (Case Study in PT. Dada Indonesia). Universal Journal of Management, 3(8), 318-328.

Mohammadkhani K, dan Lalardi M. Nasiri, 2012. Emotional Intelligence and Organizational Commitment between the Hotel Staff in Tehran, Iran. American Journal of Business and Management, 1(2), 54-59.

Mohammed, Fatema dan Eleswed, Muath, 2013. Job Satisfaction and Organizational Commitment: A Correlational Study in Bahrain. International Journal of Business, Humanities and Technology, 3(5), 43-53.

Najafi Sajad, Noruzy Ali, Azar Hemin Khezri, Shirkouhi Sajad Nazari, Dalvand Mohamed Reza, 2011. Investigating the relationship between organizational justice, psychological empowerment, job satisfaction, organizational commitment and organizational citizenship behavior: An empirical model. African Journal of Business Management, 5(13), 5241-5248.

Novebry C.W dan Eddy M.S, 2013. Pengaruh kualitas Leader Member Exchange (LMX) Terhadap Produktivitas Kerja Melalui Kepuasan Kerja Dan Komitmen Organisasional Pada PT.Nutrifood Surabaya. Indonesia: AGORA, 1(1).

Orhan, Nazife dan Dincer, Hasan, 2012. The Impacts of Emotional Intelligence Competency On Job Satisfaction In The Service 
Sector: An Application On The Turkish Banking Sector. Asian Economic and Financial Review, 2(5), 617-634.

Raza Ali, Saleem Sharjeel, Qamar Beenish, 2014. An Investigation of the Impact of Emotional Intelligence on Job Performance through the Mediating Effect of Organizational Commitment: An Empirical Study of Banking Sector of Pakistan. Information and Knowledge Management, 4(10), 19-26.

Seyal, Afzal H dan Afzaal, Taha, 2013. An Investigation of Relationship among Emotional Intelligence, Organizational Commitment and Job Satisfaction: Evidence from Academics in Brunei Darussalam. Canada: International Business Research, 6 (3), 217-228.

Sandhu, Ramesh, 2015. Impact Of Emotional Intelligence And Attitude Towards Teaching On Job Satisfaction. India: International Journal of Research in Engineering, IT \& Social Science, 5(1), 47-58.

Sinambela, Lijan Poltak, 2012. Kinerja Pegawai Teori Pengukuran dan Implikasi. Edisi I. Yogyakarta: Graha Ilmu.

Sopiah. 2008. Perilaku Organisasi. Edisi

Tiur A.S, 2013. The Effect of Interpersonal Communication, Organizational Culture, Job Satisfaction, and

Achievement Motivation to Organizational Commitment of State High School Teacher in the
District Humbang Hasundutan, North Sumatera, Indonesia. International Journal of Humanities and Social Science, 3(12), 248-264.
I. Yogyakarta: Andi Offset. 